\title{
Lumen
}

Selected Proceedings from the Canadian Society for Eighteenth-Century Studies

\section{Constructing the Past, Construing the Future: Time and History in the Garden Space of Stowe}

\section{Lisa M. Zeitz}

Volume 18, 1999

Representations of Time in the XVIIIth Century

Le temps et ses représentations au dix-huitième siècle

URI : https://id.erudit.org/iderudit/1012376ar

DOI : https://doi.org/10.7202/1012376ar

Aller au sommaire du numéro

Éditeur(s)

Canadian Society for Eighteenth-Century Studies / Société canadienne d'étude du dix-huitième siècle

ISSN

1209-3696 (imprimé)

1927-8284 (numérique)

Découvrir la revue

Citer cet article

Zeitz, L. M. (1999). Constructing the Past, Construing the Future: Time and History in the Garden Space of Stowe. Lumen, 18, 201-213.

https://doi.org/10.7202/1012376ar

Copyright (c) Canadian Society for Eighteenth-Century Studies / Sociéte canadienne d'étude du dix-huitième siècle, 1999
Ce document est protégé par la loi sur le droit d'auteur. L'utilisation des services d'Érudit (y compris la reproduction) est assujettie à sa politique d'utilisation que vous pouvez consulter en ligne.

https://apropos.erudit.org/fr/usagers/politique-dutilisation/ 


\section{Constructing the Past, Construing the Future: Time and History in the Garden Space of Stowe}

\section{Constructing the Site / Sight}

In the heart of winter, January 21,1710, readers of The Tatler were treated to a dream vision describing an allegorical landscape of laurels, honour, and civic virtue. The dreamer (Joseph Addison), finding himself faced with a choice of roads in the centre of a wood, decides to join

the middle-aged Party of Mankind, who marched behind the Standard of Ambition. The great Road lay in a direct Line, and was terminated by the Temple of Virtue. It was planted on each Side with Lawrels, which were intermixed with Marble Trophies, Carved Pillars, and Statues of Law-givers, Heroes, Statesmen, Philosophers, and Poets. The Persons who travelled up this great Path, were such whose Thoughts were bent upon doing eminent Services to Mankind, or promoting the Good of their Country. ${ }^{1}$

The description continues, depicting further elements in this imaginary landscape; on the other side of the Temple of Virtue, awaiting those who display the probity to pass through it, is the Temple of Honour; to the side of that temple, however, there is a structure of similar design, but made of 'Stones [...] laid together without Mortar' and placed upon 'so weak a Foundation, that it shook with every Wind that blew. This was called, The Temple of Vanity' (ibid.). As George Clarke has argued, Addison's essay 'provided the programme' for a key component (the Elysian Fields) of the most famous Georgian landscape garden in England: Stowe. The site's 'essential features' were 'all there' in The Tatler:

a straight long path (the Great Cross Walk) was terminated by a Temple of Virtue (Ancient Virtue), beyond which (over the Styx) lay a temple of Honour (British Worthies); nearby was a ruinous Temple of Vanity (Modern Virtue). ${ }^{2}$

In a very real sense, then, Stowe originates as a vision - an imaginative projection of familial and national identity and destiny, and a 
particular reconstruction and redisposition of the past. Indeed, it is through the production and manipulation of space at Stowe that a 'view' of the past is constructed and a 'prospect' of the future projected. Those who 'march' through the allegorical landscape described above (and materially realized at the Temple family's estate) are people with ambition, people who, through their determined progress along the 'direct' (straight) path of virtue, devote their lives to public service. Addison's description of the figures in his vision offers important evidence of one way in which the garden at Stowe may have been experienced by visitors. Those who 'travelled up this great Path' lined with laurels are represented as people involved in national enterprise, 'whose Thoughts were bent upon doing eminent Services to Mankind, or promoting the Good of their Country.' Placed in an allegorical landscape of this kind, the viewer experiences a metaphorical change in 'position' and a shift in the perception of individual identity, for the setting imaginatively redefines who the spectator is - and what he/she is doing in this place. For a time, I would argue, the walker is constructed as a figure in a heroic landscape. In a way, the garden is a living allegory, a kind of eighteenthcentury 'virtual reality' - a work of art that only fully 'means', or is completed as an aesthetic experience, when it is physically animated and experienced by the human perceiver. The viewer/walker assumes a role in the history that is staged at Stowe - he/she becomes part of the history painting, part of the landscape.

That landscape is a 'cultural image', 'a body of determinate signs', 'a textual system, ${ }^{3}$ is now an axiomatic position in the fields of cultural geography, garden history and landscape aesthetics. As Denis Cosgrove and Stephen Daniels remind us, 'a landscape park is more palpable but no more real, nor less imaginary than a landscape painting or poem ${ }^{4}$ or, we might add, a dream vision. Stowe was imagined and developed (in the 1720s, 30s, and 40s) ${ }^{5}$ by Richard Temple (1675-1749) - made Baron Cobham in 1714 and then Viscount in 1718 - to bolster his, and his family's political influence and, it has been argued, to articulate the 'Whig' (or perhaps more correctly - in the 1730s - the 'Opposition Whig') view of the history and destiny of England. As the years went on, however, Stowe's specific political critique was largely forgotten, and instead the garden came to express an increasingly shared national and imperial vision of the future of Britain. If we contrast Stowe in the 1730s with Stowe in the 1760s (when Cobham's successor, Earl Temple, had put an even greater imperial stamp on the gardens), we see a landscape that is, I would argue, less 'Whig history' and more a narrative of the historic destiny of a nation - fulfilled.

The experiencing of the landscape garden as a kind of historical narrative is achieved through the visitor's progression through the 
garden space. With guidebook to this legible landscape in hand, the walker stands in relation to the garden as a reader to a text. Indeed, walking itself becomes a metaphor for hermeneutical activity. While the complete circuit outlined by contemporary eighteenth-century guidebooks cannot exactly be described as a 'time line', there are sections of the garden which are arranged in a sequence that explicitly invites the viewer to make a connection between the past and present. The walker's movement through the garden space metaphorically represents a movement through history, a meditation upon and interpretation of Britain's place as heir to republican Rome. In the routes prescribed by both Seeley's and Bickham's guidebooks, for instance, the temples of Ancient and Modern Virtue are encountered before the Temple of British Worthies. The visitor contemplates the British Worthies (figures from Britain's past) on the way to the Temple of Concord and Victory and the Cobham Pillar - monuments to the nation's 'present' achievements. The rhythm here suggests a march, a progress - perhaps even a structure of prophecy and fulfilment, a kind of secular typology. Movement through the space occupied by these garden buildings symbolically represents a progress through time, and the physical visual prospects enjoyed from each of these sites also function as historical and moral prospects. The gaze of the walker, I shall show, is directed and constrained by the placement of objects in very carefully designed spatial relationships with each other - spatial relationships that encode and invite a particular reading of the garden's visual and metaphorical prospect views.

\section{Inscribing Britons}

The idea of a garden as a semiotic system, a complex field that 'marks space with a network of signs, with ideological content', ${ }^{6}$ would not have been foreign to the designers of this most textual of eighteenth-century landscapes. The signs that constitute the languages of Stowe include formal elements such as hills, valleys, and lakes; architectural features employing both classical and Gothic elements; and actual texts inscribed on monuments, in garden buildings and on sculpture. The placement of monuments allowed the garden's designers to write a narrative of the past on the Buckinghamshire landscape; monuments were carefully sited at Stowe in order to inscribe, and then invite viewers to discern, an interpretation of the historical past. History (ancient and modern) is represented both in the monuments of the garden itself and in the contemporary guidebooks that directed - even dictated - visitors' interpretations of and responses to this designed landscape. Increas- 
ingly, as the history of Britain in the eighteenth century unfolded, Stowe's monuments could be read as a narrative of imperial progress.

As one moved through the garden, individual features were brought into the visitor's field of vision in ways that invited links between past and present, and encouraged speculation about the future. Individual garden elements were designed to be understood and assessed in relation to the whole. The comments on how to judge gardens (the Royal Gardens at Richmond and 'the celebrated Gardens of STOWE') in The Daily Gazetteer of September 18, 1735 are typical, and illustrate the importance of visitors' '[judging] of [...] Propriety' through actively linking the landscape's elements together into a larger view: 'every Piece of Architecture, every Monument, every Walk, receives peculiar Graces from the Advantage of its just Disposition, and from its Connexion with every Thing in its View. ${ }^{7}$ In an encoded landscape like Stowe, of course, visual links have a hermeneutical function: they are contrived to offer political comments upon past and present national policies. Walkers are invited to reflect upon where the British Worthies stand in relation to the Britons of the present and to the accomplishments of the past. How do current achievements compare? What kind of future do Britons foresee for themselves? Stowe renders space an instrument of historical interpretation. The eye becomes a medium of historical awareness.

The garden's monuments invoke both the classical and the British (Gothic) past in their architectural forms and in their inclusion of statues and busts of both ancient and modern historical figures. William Kent's Temple of British Worthies (1734-35), located in Stowe's recreation of a classical 'sacred landscape' (the Elysian fields) and in the form of an exedra, has been linked with (1) the busts of Roman emperors in niches in the Italian Renaissance garden at the Villa Brenzone; (2) the exedra in the 'Renaissance recreation of a classical funerary garden' at the Villa Mattei in Rome; ${ }^{8}$ and (3) 'a Roman wayside shrine. ${ }^{\prime 9}$ The imperial, elegiac, and 'sacred' associations of these three architectural models from the past are all appropriate given the location of the Temple in the Elysian fields, and the honouring of empire-building and colonial expansionism implied in the inscriptions accompanying the busts which celebrate, as Gilbert West put it, 'a sacred Band / of Princes, Patriots, Bards and Sages. ${ }^{10}$ 'We think 'tis heav' $n$ ', Samuel Boyse wrote in his lengthy verse description of the garden, 'and leave the world behind. / So shine with native [my emphasis] pomp the realms of light' (295-96); here is a thoroughly Anglicized Elysium where 'native' illumination elides with the classical realms of light to recreate a sacred landscape - but one which is used to endorse a national myth.

The inscriptions honouring the sixteen 'British Worthies' appear above the busts and are particularly important to the interpretation of 
the garden. They are, of course, in English not Latin. The worthies are divided into 2 groups: 8 men of thought on the left, and 8 of action on the right. ${ }^{11}$ It is among the action heroes that we find Queen Elizabeth the First, the only female worthy; West celebrated her as an 'Imperial Maid' (101) during whose reign 'Industrious Commerce courted every Gale, / And spread in distant Worlds her fearless Sail' (107-08). Sir Francis Drake, the inscription above his bust reads, 'was the first of Britons that adventur'd to sail round the Globe; and carried into unknown Seas and Nations the Knowledge and Glory of the English Name'. The inscription above the bust of Sir Thomas Gresham reads, 'Who, by the honourable Profession of a Merchant, having enrich'd himself, and his Country, for carrying on the Commerce of the World built the Royal Exchange.' Even the contemplatives are celebrated as contributors to an empire of the mind and spirit. The language of expansiveness, range, and a genius superior to that of other nations marks their inscriptions. Milton, for example, is honoured as one, the inscription reads, 'Whose sublime and unbounded Genius equal'd a Subject that carried him beyond the Limits of the World.' West articulates the high claim for British culture that the inscription implies, and characterizes the national genius as rivalling that of the ancients:

Thou too, bold Milton, whose immortal Name, Thy Country dares to match with Homer's Fame;

Whose tow'ring Genius vast and unconfin'd,

Left ev' $n$ the Limits of the World behind. (143-46)

The response of William Gilpin's two visitors in his Dialogue upon the Gardens [...] at Stow is probably typical by mid-century: as they stand before the Temple, one asks the other, '[d]oes not your Pulse beat high, while you thus stand before such an awful Assembly? ${ }^{12}$

\section{Vision as Hermeneutics}

Another monument intended to raise the patriotic heart rate was a memorial column raised to honour one of the family's own members. When Captain Thomas Grenville was killed in active duty against the French in $1747^{13}$ while in command of the ship Defiance, a commemorative monument in the form of a triumphal Roman rostral column was erected on the northern side of the Grecian Valley. ${ }^{14}$ Because the original plans for the Grecian Valley included the creation of an artificial lake, this monument to a naval officer, with its sculpted anchors and projecting prows of ships (or rostra), would have been most fittingly reflected 
by the water it overlooked. Although the flooding of the Grecian Valley seems to have been attempted, ${ }^{15}$ the project was abandoned (along with a planned triumphal arch at the head of the Grecian Valley that would have terminated the view directly ahead from the portico of the Temple of Concord and Victory). ${ }^{16}$ In 1756, the year that the 'War for Empire' with France began, the Grenville monument was relocated in the Elysian Fields (its present location), and the former statue of Neptune holding a splinter of Grenville's ship was eventually replaced by a lead figure of the muse of heroic poetry. What I find most interesting about the re-siting of the Grenville Monument is the way in which the text of the landscape has been revised and rewritten by bringing the column into relation with the Temple of British Worthies, the Temple of Ancient Virtue, and the Gothic Temple.

After a visitor has read the elegy on the monument (a poetic tribute in English by George, Lord Lyttelton), he/she looks up and in the direct line of vision is the Temple of British Worthies. Lyttelton's inscription is no longer legible, but it was printed (for the first time) in the Seeley guidebook of 1766; the elegy links Grenville to a great Elizabethan poet, officer, and aristocrat who also died in battle. The elegy reads in part,

Ye weeping Muses, Graces, Virtues, tell

If since your all-accomplish'd Sidney fell,

You, or afflicted Britain, e'er deplor'd

A Loss like that these plaintive Lays record [...]

He too, like Sidney, nurs'd in Learning's Arms,

For nobler War forsook her peaceful Charms; [...]

Like him, cut off in youthful Glory's Pride,

$\mathrm{He}$, unrepining, for his Country dy'd. (Seeley 22)

Service to one's country and a 'heroic' military death marks one as a worthy heir to a line of national greatness, and secures immortality: the Latin inscription around the column's base [DIGNVM LAVDE VIRVM MVSA VETAT MORI] is translated in the 1763 guidebook as 'The Muse Forbids Heroic Worth to Die'. It is worth noting that the figure of Heroic Poetry, holding the scroll of immortality which reads, 'Of none but heroic deeds I sing', faces the Gothic Temple, thus also joining Grenville to the 'ancient' ancestors of Britons whom West had described as 'our renown'd Fore-Fathers' - 'a Nation, valiant, wise, and free, / Who conquer'd to establish Liberty' $(315,317-18)$. Captain Grenville's life, as celebrated by the monument, and as suggested by the visual links, represents a fulfillment of the British Worthies' vision of the future and a monitory example of a contemporary who shows himself to be a true 
son of the Saxons ('renown'd Fore-Fathers'), the monument to whom enjoys the highest location in the garden on the brow of a hill.

A visitor standing in the Temple of Ancient Virtue and looking out to the Grenville monument views it through a door above which is a Latin inscription, part of which reads (and I use the translation provided in the 1756 guidebook), 'To be dear to our Country, to deserve well of the State, to be honoured, reverenced, and loved is truly glorious [...]' (20). That Grenville stands as a modern example of an 'ancient virtue', and a model Briton whose example should inspire future heroes is clear from the lengthy didactic inscription on his monument; the English translations of the concluding lines become increasingly exhortative: whereas the 1749 guidebook reads,

This is, alas! a rare Instance

Of true English Bravery;

From which let all British Officers

Learn their Duty (22)

by 1756 (the start of the Seven Years War) the tone has changed from elegiac to hopeful: 'May this noble instance of Virtue / Prove instructive to an abandoned Age, / And teach Britons how to act / In their Country's Cause' (27). The final major change in the translation occurs in 1763, and what was before expressed as an aspiration has now become an order; the reader is commanded

From this animating Example

Learn

When honoured with Command

To think, and act, as becomes

An Officer.

A future of military glory awaits those 'honoured with Command' if they are animated by Grenville's - and the garden's - 'Example.'

\section{The View as a Vision of History}

By reinvigorating the greatest architectural achievements of the classical and medieval past, and redisposing and inscribing this past with a version of the present and an agenda for the future, the builders of Georgian landscape gardens make a claim to both aesthetic and national supremacy. The designers of Stowe transform both space and time in their disposition of history and art into a new vision of Britain's identity 
and destiny. While the eighteenth-century landscape garden, as a work of art, exists in the here and now, it was also created to be, as John Dixon Hunt has observed, a 'living history painting.' A garden must be experienced; the viewer, uniquely in this art form, inhabits the 'painting' in a physical sense. The garden space at once regulates the walker's movement and integrates spectators within the frame. There is no allegorical meaning without the eighteenth-century visitors moving in and through this vision of Britain's destiny - for they are her destiny, her future, her nationhood. British spectators traversing the landscape become part of the historical vision at Stowe; here are the heirs of the Saxon forefathers (represented by the Saxon Deities, seven statues by Rysbrack that by 1745 had been placed on the eastern side of the Gothic Temple) and the Elizabethan adventurers (memorialized by the Temple of British Worthies): the present and the future warriors and builders of empire. The visitors animate the landscape and complete Stowe's vision for they, too, are Britons, the inhabitants of this country. The effect on the perceiver (his/her redisposition or reconfiguration) within the historical scenes that the garden creates) is what this landscape is 'about.' Indeed, the landscape becomes fully 'heroicized' only when living figures (like Addison's dreamer) join the cast already present in this theatre of a visitable virtual past.

Without doubt the most heroic element at Stowe is the substantial temple overlooking the Grecian Valley - and originally called the Grecian Temple - begun in 1747, altered in the 1750s, and renamed the Temple of Concord and Victory in 1762 in celebration of Britain's victory over the French in the Seven Years War. Described in Seeley's guidebooks as 'one of the principal Ornaments in the Garden', its interior decoration offers a kind of summary of Britain's progress towards Empire, with its fourteen plaster wall medallions (mainly copied from the victory medals of the Society of Arts) celebrating conquests in Africa, India, the West Indies, Europe and Canada. Of these parts of the world, Canada figures most prominently. Three medallions commemorate the 'taking of' (as it is phrased in Seeley's guidebooks) Quebec, Louisbourg, and Montreal; two more medallions celebrate the 'Conquest of Canada' and 'Canada subdued.' As Patrick Eyres points out in an excellent essay entitled 'Neoclassicism on Active Service: Commemoration of the Seven Years War in the English Landscape Garden', these five medallions constitute one third of the scheme and '[emphatically] represent [...] Canada as the jewel in the imperial swagbag. ${ }^{17}$ The promise offered by the newly-installed bas-relief sculpture on the pediment of the temple's exterior - which represents the four Quarters of the World bringing their various Products to Britannia ${ }^{18}$ - is fulfilled in the interior decora- 
tion commemorating Great Britain's continually expanding empire through its military victories.

The best example of what might be described as 'the prospect as a vision of history' is the view from the Temple of Concord and Victory. From the top of the temple's steps one looks diagonally to the right and sees Lord Cobham's Pillar, a 115 feet high tower that was Lady Cobham's tribute to her husband. Turning left and on a diagonal the view through the open fields is stopped by the 100 feet high obelisk in memory of General Wolfe. The location of the monument to the hero of the Seven Years' War is apt: it is to the North-West of the garden and outside its boundaries. The imperial centre has been projected beyond the garden's peripheries, and new spaces outside the garden's borders are marked by symbols of conquest and colonization just as British culture and institutions are projected and inscribed in 'new' world landscapes. The visual linking of these three elements is not left to chance: the description in the guidebook of 1763 clearly directs the viewer to consider these features together. The uniting of the Temple of Concord and Victory, the obelisk to the memory of General Wolfe (who died on the Plains of Abraham in Quebec) ${ }^{19}$ and the Cobham column makes its own contribution to both the narrative of empire and the project of family aggrandizement at Stowe, for 'the successful conduct of the Seven Years' War was seen as the vindication of the political ideals fostered at Stowe. ${ }^{20}$

Perhaps the most brilliant production of space at Stowe is the trick of perspective at the end of the approach from Buckingham where an eye-catcher on a truly Brobdingnagian scale (60 feet high and 60 feet wide), the Corinthian Arch, was built in 1765-67. The Arch forms the focal point of the view from the South Front, a breathtakingly beautiful picture. But perhaps more powerful is the effect as one approaches the estate from Buckingham. As one looks down the rolling road of 1.5 miles (known as the Grand Avenue or Stowe Avenue), the South Front of the House completely fills the frame of the Corinthian Arch. Earl Temple (Cobham's successor) had the new drive laid out in 1775, building it 'straight from Buckingham in alignment with both Arch and House.'21 The result of this extraordinary reshaping of perspective is a telescoping and collapsing of space that renders the house and the triumphal arch simultaneously present. The optical illusion draws the house forward to meet the arch. The symbol of the family (the house) is thus framed in triumph. What does this brilliant visual conceit signify? If Britain now rivals Rome, it is in no small part thanks to the Temple and Grenville families. The British present and the greatest achievements of the classical past are 'one' - simultaneously joined in perfection. The past itself is colonized: Britain has absorbed, made her own, and progressed beyond the glory that was Greece, the grandeur that was Rome. Time is 
'claimed' for Britain, as the architectural and cultural achievements of the ancients are seen to 'migrate' - through acts of appropriation, of course - to an eighteenth-century England that repossesses and surpasses them.

At Stowe, the 'general kinaesthetic pleasures of moving in and through a space ${ }^{\prime 22}$ that any garden affords are transformed into an allegorized and intellectual experience. For movement through space here is analogous to movement through time. Put another way, the space constructed at Stowe simultaneously produces both a landscape and a timescape in and through which the walker moves. W.J.T. Mitchell has recently urged that we think of landscape 'not [my emphasis] as a text to be read, but a process by which social and subjective identities are formed. ${ }^{23}$ I have tried to show how the active engagement with the landscape of Stowe through the dynamic process of walking through the garden is also a process of reiterating national identity - of defining oneself as a Briton. Stowe allows its visitors to situate themselves in a landscape, and in so doing, to situate themselves in history. ${ }^{24}$ For in this landscape garden which constructs a narrative of imperial progress using a vocabulary of space, 'ways of seeing' are 'ways of telling.'

\section{LISA M. ZEITZ}

University of Western Ontario

\section{Notes}

1 The Tatler, ed. Donald F. Bond, 3 vols. (Oxford: Clarendon, 1987) 2: 224-25 (Number 123).

2 George Clarke, 'Grecian Taste and Gothic Virtue: Lord Cobham's Gardening Programme and its Iconography', Apollo 97 (June 1973) 567.

3 See, for example, the introduction to The Iconography of Landscape, ed. Denis Cosgrove and Stephen Daniels (Cambridge: Cambridge UP, 1988) 1, and Landscape and Power, ed. W.J.T. Mitchell (Chicago: U. of Chicago P., 1994) 1. Henri Lefebvre's The Production of Space (1974), trans. by Donald Nicholson-Smith (Oxford: Basil Blackwell, 1991), remains the most important and influential theoretical discussion of social space; as Lefebvre writes, any 'already produced space can be decoded, can be read. Such a space implies a process of signification' (17).

4 Cosgrove and Daniels 1.

5 The gardens grew from 24 acres in 1724 to about 205 acres in 1748; see John Beckett, The Rise and Fall of the Grenvilles; Dukes of Buckingham and Chandos, 1710 to 1921 (Manchester: Manchester UP, 1994) 21. 
6 So Richard Peet and Nigel Thrift have described how political systems organize space; see New Models in Geography: The Political-Economy Perspective, ed. Richard Peet and Nigel Thrift, 2 vols. (London: Unwin Hyman, 1989) 2:11.

7 F. Walsingham, 'Reflections on the Craftsman's Insolence to the Royal Family', The Daily Gazetteer 70 (September 18, 1735).

8 See John Dixon Hunt, William Kent, Landscape Garden Designer. An Assessment and Catalogue of his Designs (London: A. Zwemmer, 1987) 53-54.

9 National Trust's current guidebook to Stowe.

10 West's poem 'Stowe, The Gardens of the Right Honourable Richard Lord Viscount Cobham' (1732) and Samuel Boyse's 'The Triumphs of Nature' (1742) are both reprinted with informative introductions in G.B. Clarke's collection of primary sources, Descriptions of Lord Cobham's Gardens at Stowe (1700-1750) (Aylesbury: Buckinghamshire Record Society, 26, 1990) 36-51, 94-110. Further references are to this edition and will be incorporated as line citations.

11 From left to right are seen the busts of the eight figures of thought - Alexander Pope, Sir Thomas Gresham, Ignatius (Inigo) Jones, John Milton, William Shakespeare, John Locke, Sir Isaac Newton, and Sir Francis Bacon - and the eight figures of action - King Alfred, Edward (Prince of Wales), Queen Elizabeth, King William III, Sir Walter Raleigh, Sir Francis Drake, John Hampden, and Sir John Barnard.

12 [William Gilpin], A Dialogue upon the Gardens of the Right Honourable the Lord Viscount Cobham, at Stow in Buckinghamshire, 2nd edition (London: B. Seeley, 1749) 26. The Worthies are separated by both a river and a slope from the Temple of Ancient Virtue. I read those features as suggesting (among other possibilities) the separation of time, an honouring of the classical inheritance, and the 'moral' that immortality is not attained without struggle and the effort of aspiration - but I do not think that the site of Ancient Virtue in a higher location indicates a moral diminishment of the Worthies (as some interpreters, like John Dixon Hunt in 'Emblem and Expressionism in the Eighteenth-Century Landscape Garden', ECS 3 (1971) 294-317, have suggested). While the ironic mock-panegyric to Signor Fido (the Italian Greyhound) on the back of the Temple of British Worthies certainly rendered the tone of the monument more complex, especially to the cognoscenti of Lord Cobham's time, Fido's memory was erased by 1763 when his slab was moved to a less prominent location; see George Clarke, 'Signior Fido and the Stowe Patriots' Apollo 122 (Oct. 1985) 248-51. There is nothing in eighteenth-century guidebooks - aimed at the garden tourist - to suggest that the Worthies were not taken seriously.

13 He died as a result of wounds received in action off Cape Finisterre in May 1747.

14 As David R. Coffin explains in his recent book on commemorative monuments in English gardens, The English Garden: Meditation and Memorial (Princeton: Princeton University Press, 1994), '[this] Doric column was a version of the ancient Roman rostral columns that once stood in the Roman Forum with shafts featuring the prows of Roman galleys' (207). As George Clarke notes, the Grenville column was first erected on the far side of the Grecian Valley, but 'Earl Temple moved it to a more appropriate position at the entrance to the Elysian Fields, near the other British heroes.' See 'The Moving Temples of Stowe: Aesthetics of Change in an English Landscape over Four Generations', Huntington Library Quarterly 55 (1992) 506. 
15 Seeley's guidebook of 1749 (22) describes 'a large Bason of Water, where will be on the Side next the Park a Triumphal Arch.' Joan Coutu has suggested that the triumphal arch was abandoned because Cobham was dissatisfied with the results of the War of the Austrian Succession, and the terms of the Treaty of Aix-la-Chapelle: 'Perhaps the triumphal arch, which was to have been inscribed "Fortunae Britannicae Domi Forisque" (British Fortune at Home and Abroad) was never built because there was no triumph to commemorate.' See 'Stowe: a Whig Training Ground', New Arcadian Journal, 43/44; The Political Temples of Stowe: Papers on Aspects of the Political Iconography of Stowe Landscape Garden c.1730 c.1770 (1997) 70.

16 The foundations for the triumphal arch were dug in 1752 but filled in four years later; the scheme may have inspired the later Corinthian Arch. See Michael Bevington's very useful 166-page guide, The Garden and the Park, 3rd edition (Stowe: Capability Books, 1996) 102.

17 Patrick Eyres, 'Neoclassicism on Active Service: Commemoration of the Seven Years War in the English Landscape Garden', NAJ 35/36 (1993) 87.

18 Scheemaker's bas-relief sculpture of Britannia receiving tribute had been removed from the back wall of the Palladian Bridge, and redeployed here in 1761 (now in triangular shape) in a more visible, iconographically powerful site on a rise overlooking a valley. The imperial theme of the relief was easily adapted to England's victory; indeed, the aptness of the image itself was enhanced by the triumphant campaigns abroad.

19 Vanbrugh's guglio or fountain (in the form of an obelisk), originally in the octagon pond, and taken down when the pond was naturalized, was recycled and used to construct the monument (over 100 feet in height) to General Wolfe. It is also worth noting that in 1764 the structure Gilbert West had referred to in 1732 as 'Gibbs' Building' was moved from the west garden and rebuilt as the Fane of Pastoral Poetry in order to frame a view of Wolfe's obelisk. Appropriately, it was around the original building (also known as the Belvedere) that (to quote West's verse) 'a sacred Band / of Princes, Patriots, Bards and Sages stand.' The eight busts described became the first inhabitants of the Temple of British Worthies.

20 John Martin Robinson, Temples of Delight: Stowe Landscape Gardens (London: George Philip, in association with The National Trust, 1990) 118.

21 Michael Bevington, Templa Quam Dilecta 1, 11.

22 Stephanie Ross, 'Gardens, Earthworks, and Environmental Art', Landscape, Natural Beauty and the Arts, ed. Salim Kemal and Ivan Gaskell (Cambridge: Cambridge UP, 1993) 159.

23 Mitchell 1.

24 My thinking here is influenced generally by John Berger's seminal work in Ways of Seeing, Another Way of Telling, and The Sense of Sight.

* I gratefully acknowledge the support of the Social Sciences and Humanities Research Council of Canada which funded several weeks' research at Stowe School and its Garden Resource Centre. I also wish to express my sincere thanks to Michael Bevington, Head of Classics and School Archivist, for many kindnesses. 
** The author invites interested readers to take the interactive virtual walking tour of Stowe (and examine the views described in this essay) on John Talter's remarkable website: <http://panther.bsc.edu/ jtatter/stowe.html>. 